IJLR: International Journal of Law Recontruction

Volume 5, Number 1, April 2021

DOI : http://dx.doi.org/10.26532/ijlr.v5i1.15321

\title{
RESTITUTION RIGHTS AS A CONSTRUCTION OF JUSTICE REFERRING TO THE LAW ON PROTECTION OF WITNESSES AND VICTIMS
}

\author{
Bambang Tri Bawono \\ Sultan Agung Islamic University \\ bambang@unissula.ac.id
}

\begin{abstract}
This study aims to determine the effectiveness of restitution rights regulations for witnesses and victims based on Law No. 31 of 2014 concerning Amendments to Law No. 13 of 2006 concerning Protection of Witnesses and Victims. The provision of restitution which is the right of victims is often neglected, so that victims in their capacity as the aggrieved party do not get the rights that should be as stipulated in legislation. Based on this, this research emphasizes more on the factors that cause the ineffectiveness of regulations regarding restitution rights, as well as how efforts should be made so that victims can get restitution rights in accordance with the value of justice. The research method used in this research isresearch method library with a normative juridical approach that emphasizes secondary data in the form of primary legal materials, secondary legal materials, and tertiary legal materials. The results of the research state that the factors that cause the ineffectiveness of restitution rights are the victim's ignorance of the existence of the right to retribution and the procedure for filing it, the perpetrators of criminal acts are generally incapacitated, and there is no good faith for the perpetrators of crimes who generally have adequate financial capacity. Efforts that must be made so that victims get the right to restitution is to replace the application of the service model for victims of criminal acts that should position the victim as a subject who needs extra services, as stated in Law No. 21 of 2007 concerning the Eradication of the Crime of Trafficking in Persons. In addition, the current effort is to make the replacement of the right to restitution as an additional punishment which automatically becomes part of the judge's decision to be implemented immediately.
\end{abstract}

Keywords: Justice, Restitution Rights, Victims.

\section{A. INTRODUCTION}

The concept of justice in Pancasila requires every human being to have a humane attitude to build relationships between people. The existence of a humane attitude demands that everyone has equal rights regardless of gender, ethnicity, religion, race, social class, and so on. Based on that fact, just and civilized humanitarian principles become the basis for protecting human rights by civilizing human beings without reducing their rights at all. ${ }^{1}$ The existence of a just humanity

1 Ferry Irawan Febriansyah, Justice Based on Pancasila as the Philosophical and Ideological Basis of the Nation, DiH Journal of Legal Studies, Vol. 13, No. 25, 2017, page. 6. 
like this results in humans having to uphold human dignity as a creature of God Almighty, uphold human rights, respect dignity for equal rights and degrees without distinguishing ethnicity, race, religion, social status, descent. etc., as well as developing an attitude of mutual love, tolerance, being arbitrary, and upholding human values. ${ }^{2}$ For the sake of realizing this value of justice, the state has the responsibility to protect the rights of every citizen so that it is not harmed by other parties. Based on this responsibility, the state firmly guarantees the rights of every citizen as stipulated in the 1945 Constitution. The existence of such a guarantee ultimately results in the state having the obligation to provide rights and equality between one party and another. Therefore, the state also has a moral responsibility to provide justice for parties who injure each other. Especially in the context of criminal law, the state, representing the interests of the community, is obliged to impose criminal sanctions on criminals and restore the victim's condition by providing compensation in the form of restitution or compensation. In this regard, the provisions regarding the victim's right to get restitution are regulated in Article 7A paragraph (1) of Law No. 31 of 2014 concerning Amendments to Law No. 13 of 2006 concerning Protection of Witnesses and Victims. In this Article, it is explained that victims of criminal acts are entitled to receive restitution in the form of:

1. Compensation for loss of wealth or income;

2. Compensation for losses arising from suffering directly related to a criminal act.

3. Reimbursement of medical and / or psychological treatment costs.

In addition to the right to restitution, the state also regulates the right to compensation for victims of serious human rights violations and victims of criminal acts of terrorism. Furthermore, victims of human rights violations and victims of criminal acts of terrorism also receive medical assistance and psychosocial and psychological rehabilitation assistance as contained in Article 6 and Article 7 of Law No. 31 of 2014 concerning Amendments to Law No. 13 of 2006 concerning Protection of Witnesses and Victims. Referring to such provisions, the right to restitution, compensation, and psychological and psychosocial assistance is a right that should be obtained by the victim. However, the facts that occur in the field show that many victims do not get these rights due to the crimes that befell them. This is due to the fact that criminal law enforcement efforts generally only focus on proving a crime, meanwhile the victims of criminal acts must fight for compensation themselves.

This fact becomes increasingly clear when referring to one of the studies conducted by Sujoko who is in the jurisdiction of the city of Semarang. The results of the research from Sujoko emphasized that no victim of a crime, especially rape, has filed a lawsuit for merging claims for compensation against the perpetrator of a criminal act. In fact, the petition for filing a claim for compensation against the perpetrator of a criminal act is expressly regulated in Article 98 of the Criminal Procedure Code. The reason for the ineffectiveness of this article is due to the

2 Mochlisin, Kwarganegaraan, Interplus, Jakarta, 2007, page. 11. 
ignorance of the victim, who in fact is an ordinary person, about the rights that the victim can accept. ${ }^{3}$

In line with this research, based on data presented by witness and victim protection agencies, it was stated that during 2018 to 2019, the total services provided by witness and victim protection agencies had reached 9308 services. In details, 2450 procedural rights fulfillment services, 395 physical protection services, 964 psychological assistance services, 457 psychosocial assistance services, 4017 medical assistance services, 621 restitution services, and 404 compensation services. Regarding the provision of restitution in 2019, LPSK has facilitated restitution for 105 victims of criminal acts out of a total of 46 cases. Meanwhile, 61 out of 25 cases were victims of sexual violence crime and 44 out of 21 cases were victims of the criminal act of trafficking in persons. Regarding the amount of restitution facilitated in all these cases it has reached Rp. 6,312,733,233.00 (six billion three hundred twelve million seven hundred thirty-three thousand two hundred thirty-three rupiah). The total cost of restitution that was granted by the court was Rp. 1,692,944,025.00 (one billion six hundred ninety-two million nine hundred forty-four thousand twenty-five rupiah), while the amount of restitution that was not granted was Rp. 524,932,000.00 (five hundred twenty-four million nine hundred and thirty-two thousand rupiah), while the amount of restitution that is still awaiting the process of the court is Rp. 2,977,153,280.00 (two billion nine hundred seventy-seven million one hundred fifty-three thousand two hundred and eighty rupiah). ${ }^{4}$ It is undeniable that the application for such restitution rights has increased. However, looking at the number of cases that have been decided by the Supreme Court, which are 1470 general criminal cases, 4996 special criminal cases, and 320 military criminal cases, of course there is a significant difference regarding the number of cases decided with the people who apply for restitution rights. ${ }^{5}$

Based on this background, the legal substance regulating restitution rights has not been fully optimized, so that the guarantee of justice has not been fully felt by the victims. Referring to this fact, the subject matter of this study focuses more on what factors cause the weak fulfillment of restitution rights for victims, as well as what efforts should be made to ensure that victims can get restitution rights in accordance with the value of justice.

\section{B. RESEARCH METHODS}

This research is a series of procedures or steps used to manage and collect data and analyze the data using certain techniques and methods. ${ }^{6}$ The research method used in this research is library research or library research. The approach used in this study is a normative juridical approach. The normative juridical

3 Sujoko, Implementation of Claims for Compensation in Article 98 of the Criminal Procedure Code against the Crime of Rape in Semarang Legal Area, Thesis, Diponegoro University, Semarang, 2008, page. 91-92.

4 https://lpsk.go.id/berita/detailberita/3104

5 http://pa-trenggalek.go.id/informasi-pengadilan/271-sepanjang-2019-ma-memeriksa-20-275-perkara

6 Bambang Sunggono, Methodology Legal Research, Cet. Second, Raja Grafindo Prasada, Jakarta, 2010, page. 24. 
approach is a research approach that aims to examine legal principles, legal systematics, legal synchronization, legal history and comparative law. ${ }^{7}$ Meanwhile, the legal materials used in this research consist of primary, secondary and tertiary legal materials. Primary legal materials consist of statutory regulations, official records or treatises relating to this research. Meanwhile, secondary legal materials relate to legal materials that provide clarification to primary legal materials, such as books, literature, articles, papers and other materials taken from legal experts. The tertiary legal material places more emphasis on data from the internet which is intended to provide reinforcement for the object under study.

\section{RESULTS AND DISCUSSION}

\section{Of Factors Affecting The Ineffectiveness Of Regulations On Fulfilling Restitution Rights For Victims}

Legal protection of the rights of victims of crime has basically been regulated in Law No. 31 of 2014 concerning Amendments to Law No. 13 of 2006 concerning Protection of Witnesses and Victims. According to Satjipto Rahardjo, legal protection is to provide protection to human rights that have been harmed by others and this protection is given to the community so that they can enjoy all the rights regulated by law. ${ }^{8}$ In principle, legal protection is divided into two parts, namely active and passive protection. Passive legal protection is external action (other than court process) that provides recognition and guarantees in the form of arrangements or policies relating to the rights of perpetrators and victims. The active legal protection is divided into two parts, namely active preventive and active repressive. Preventive active legal protection is in the form of granting the rights of the perpetrator that must be accepted by victims in relation to the stipulation of legal rules and government policies, while active repressive legal protection is in the form of prosecutions against the government or law enforcers against the regulations and policies that have been applied to victims who are deemed harmful. ${ }^{9}$

Based on such legal protection, criminal offenses also have several rights as stipulated in legislation. In this context, the rights that can be obtained by victims are the rights to restitution, compensation, and psychological and psychosocial assistance as regulated in Article 6, Article 7, and Article 7A of Law No. 31 of 2014 concerning Amendments to Law No. 13 of 2006 concerning Protection of Witnesses and Victims. The definition of restitution according to Article 1 paragraph (5) Government Regulation no. 44 of 2008 concerning Compensation, Restitution and Funding Assistance to Witnesses and Victims is compensation given to victims or their families by perpetrators or third parties, in the form of returning property, payment of compensation for loss of

7 Laurensius Arliman S, Notary and Law Enforcement by Judges, Deepublish, Yogyakarta, 2015, page. 12.

8 Ratih Wulandari, Legal Protection for Government Employees with a Work Agreement at the Regional General Hospital, Scopindo Media Pustaka, Surabaya, 2020, page. 14.

9 Alvianto RV Ransun, Mechanism of Compensation and Restitution for Victims of Crime, Lex Crimen, Vol. 1, No. 1, 2012, page. 63. 
suffering, or compensation for certain costs. Meanwhile, Article 1 paragraph (4) explains that compensation is compensation provided by the state because the perpetrator is unable to provide full compensation which is his responsibility. However, the provisions regarding compensation are only intended for serious human rights violations and criminal acts of terrorism.

Regardless of this context, referring to Sujoko's research results and data from the LPSK which were synchronized with the number of cases decided by the Supreme Court, there was a significant difference in the number of requests for restitution made by victims and the number of criminal cases decided by the Supreme Court in 2019. This fact shows that the laws and regulations governing the rights of victims are not yet fully effective and efficient, so that victims have not been able to get their rights as regulated in the legislation. The factors that influence the rights of victims to receive restitution are not fulfilled, because the model of restitution rights regulation requires the victim's initiative to submit this right to the court. Provisions regarding filing requests must be submitted to the court through the LPSK as regulated in Article 20 paragraph (3) and Article 34 paragraph (3). Arrangements for filing the rights of victims of criminal acts like that are certainly not beneficial for victims who are in fact ordinary people. It is undeniable that the percentage of requests for restitution rights through LPSK institutions has increased. Based on the data presented from the LPSK page, it shows that the LPSK has provided facilities for the fulfillment of restitution for 105 victims of criminal acts out of a total of 46 cases. ${ }^{10}$ However, by looking at the number of cases and submissions for the right to restitution of victims, there is a significant difference, considering that in 2019 the Supreme Court decided 1470 general criminal cases, 4996 special criminal cases, and 320 military criminal cases. ${ }^{11}$

The existence of this condition is also exacerbated by the average perpetrator of criminal acts who are generally underprivileged people, so that both the perpetrator and the victim can only surrender, waiting for justice through court decisions. Referring to the results of research conducted by the Mappi Study in 2011-2015, it was found that out of 1276 light criminal court decisions in DKI Jakarta, it was found that $98.8 \%$ of the perpetrators of criminal acts were new people, while $2.9 \%$ were old players. . In connection with the results of this study, $34.4 \%$ of the perpetrators were aged $15-24$ years and were dominated by men as many as $81.9 \%$, while women were $10.5 \%$. The trigger for the emergence of these minor crimes was due to the economic conditions and the minimum level of education. Economic factors and the minimum level of education resulted in $36.7 \%$ of the perpetrators of theft due to unemployment, so that $34.7 \%$ of the objects stolen were cellphones and laptops, while $18.4 \%$ were motorbike thefts. ${ }^{12}$ With this condition, the fulfillment of restitution rights for victims of criminal acts will in fact burden the

10 https://lpsk.go.id/berita/detailberita/3104

11 http://pa-trenggalek.go.id/informasi-pengadilan/271-sepanjang-2019-ma-memeriksa-20-275-perkara

12https://www.cnnindonesia.com/nasional/20170622090822-12-223453/kejahat-di-jakarta-dipiksiincreased 
state finances, considering that the perpetrators of criminal acts are unable to pay compensation due to their actions.

Another factor that causes the ineffectiveness of regulations to fulfill restitution rights for criminals is because the perpetrators of criminal acts, who generally have the financial capacity, do not have good faith, because they think that the imprisonment that must be committed is a punishment that is commensurate with the suffering that has been experienced by them. victim. The existence of such an assumption certainly results in a criminal who has sufficient financial capacity to be reluctant to pay for his right to retribution, considering that the sentence he has served has given the victim its own satisfaction. In connection with the above discussion, it can be concluded that the factors behind the ineffective fulfillment of the right to retribution and compensation for victims of crime are as follows: The

a. ignorance of victims who are actually cloud people about the existence of the right to retribution and the procedures for filing it. The victim's ignorance is also based on a regulatory model that requires the victim's initiative to submit to court through the LPSK.

b. In general, criminals are underprivileged people, so they can only surrender themselves to waiting for justice through court decisions.

c. The ineffectiveness of the regulations on the fulfillment of the right to retribution and compensation is because the perpetrators of criminal acts, who generally have adequate financial capacity, do not have good faith, because the perpetrators of criminal acts think that the imprisonment that must be carried out is a punishment that is commensurate with the suffering experienced by the victim.

\section{Reconstruction of Regulations on Providing Restitution and Compensation for Victims of Crime Based on The Fairness Values}

Principle of justice is one of the important things that must be realized in life. This is because the value of justice highly upholds a norm which is based on impartiality, balance, and equity towards something. ${ }^{13}$ That is why Magnis Suseno defines the word fair as a condition or condition of a human being that is treated equally / equally or in proportion to their respective rights and obligations. In line with that, the concept of justice in Pancasila requires that every human being must be fair in building relationships with himself, his fellow man, his nation and state, his environment, and be fair to God Almighty. With such a concept of justice, humans must uphold human dignity as a creature of God Almighty, uphold human rights, respect dignity for equal rights and degrees without distinguishing ethnicity, race, religion, social status, descent and so on, as well as developing an attitude of mutual love, tolerance, being arbitrary, and upholding human values. ${ }^{14}$ Especially when a criminal act occurs in society, the

13 Ferry Irawan Febriansyah, Justice Based on Pancasila as a Philosophical Basis and National Ideology, DIH Journal of Legal Studies, Vol. 13, No. 25, 2017, page. 14.

14 Mochlisin, op.cit, page. 11. 
state representing the community is obliged to impose criminal sanctions and restore the rights of victims by providing compensation in the form of restitution rights.

Efforts to grant restitution rights to victims of criminal acts must also be based on the value of justice, so that no parties are harmed. In this context, regulations regarding the granting of restitution rights are still a serious problem that must be resolved immediately. This is due to the ineffectiveness of the provisions on restitution rights as contained in Law No. 31 of 2014 concerning Amendments to Law No. 13 of 2006 concerning Protection of Witnesses and Victims causes law enforcement to not proceed as desired. According to Satjipto Rahardjo, law enforcement is a process to bring legal desires into reality. What is meant by legal desires are thoughts of a legislative body formulated in statutory regulations. ${ }^{15}$ Based on this, it is necessary to reconstruct the regulations regarding the fulfillment of retribus rights for victims based on the values of justice.

As explained in the earlier discussion, the obstacle in fulfilling the right to retribution is due to three factors, namely:

d. The victims' ignorance of the existence of restitution rights and the procedures for applying them.

e. Most of the perpetrators of criminal acts are from the poor.

$f$. The absence of a good commitment from the perpetrator of a criminal act who has adequate financial capacity.

The reconstruction of regulations on the fulfillment of restitution rights caused by the ignorance of victims regarding the existence of these rights and the procedures for filing them are basically related to unbalanced models or procedures. In this case, the model for proposing restitution rights should no longer use the initiative model of the victim, considering that the condition of the victim certainly does not think about the existence of these rights, but the most important thing is to get justice. The model of fulfilling restitution rights for victims of crime should not stand alone. The regulations regarding the procedure for submitting restitution rights are making an application as referred to in paragraph (2) and submitted in writing in Indonesian on sufficiently stamped paper to the Court through the LPSK. The existence of such filing provisions should need to be evaluated, so that the criminal justice model used is more concerned with providing services to victims, which means that victims are more passive in granting restitution rights. This refers to Muladi's view that the problem of regulating crime victims is generally related to one of the objectives of punishment, which currently emphasizes conflict resolution by restoring balance and creating a sense of peace in society. In addition, this argument is also based on arguments for social contracts and arguments for social solidarity, so that the state must prioritize legal protection for crime

15 Y. Sri Pudyatmoko,Improvement Licensing: Problems andEfforts, Grasindo, Jakarta, 2009, page. 111. 
victims. ${ }^{16}$ This view is also in line with Van Apeldorn's view which states that the purpose of law is to regulate the order of society in a peaceful and just manner, so that the form of peace is always maintained through law by protecting interests, in the form of honor, independence, property, and so on. The interests of one party and another are often conflicted, causing disputes. With this dispute, the law maintains peace by weighing various conflicting interests carefully and balancing with fair regulations. Fair rules always contain a balance between the protected interests, so that everyone gets as much as possible who is part of it. ${ }^{17}$

Based on the opinion of Muladi and Van Apeldorn, the procedural model of fulfilling restitution rights requires the involvement of law enforcers, who legally play an active role in providing the rights of victims of criminal acts in accordance with statutory provisions governing them. Indeed, it cannot be denied that Article 98 of the Criminal Procedure Code also regulates the merging of criminal lawsuits with claims for compensation. It's just that, the existence of filing a lawsuit like this is rarely done, considering that apart from the victim is a layman who incidentally does not understand the procedures for the operation of the law, nor is he aware of any rules regarding such a lawsuit filing.

The application of the service model to victims of criminal acts should position the victim as a subject who needs extra services, as stated in Law no. 21 of 2007 concerning the Eradication of the Crime of Trafficking in Persons. In this Law, the fulfillment of the rights of restitution, compensation and rehabilitation in an aspirational manner positions victims as the party who is in dire need of services. The elucidation of Article 48 paragraph (1) states that the mechanism for requesting restitution is carried out since the victim reports the case that he has experienced to the local police and is handled by the investigator at the same time as the handling of the criminal act committed. Furthermore, the public prosecutor conveyed to the victim his right to apply for restitution and conveyed the amount of losses suffered by the victim as a result of the criminal act of trafficking in persons together with the charges. In this connection, JAMPIDUM technical instructions No. 371 / E / EJP / 11/2012 dated 28 November 2012 regarding Restitution in the Crime of Trafficking in Persons also stated: "are reminded to the public prosecutors who handle cases of trafficking in person where the victim has not filed for restitution at this stage. investigation: in order to inform the victim about only applying for restitution in the form of compensation. "18 The mechanism for fulfilling restitution in the Law on the Eradication of the Crime of Trafficking in Persons requires law enforcers to play a dual role, namely handling criminal cases and taking care of all the

16 Rena Yulia, Reviewing the Position of Crime Victims in the Criminal Justice System, Mimbar Hukum, Vol. 28, No. 1, 2016, page. 39.

17 Hasmiah Hamid, Legal Protection Against Victims of Torture in Handling Crime, OSF.IO, 2018, page. 5-6.

18 Republic of Indonesia Prosecutor's Training Agency, Prosecutors' Office Module on Crime of Human Trafficking, Education and Training Agency for the Republic of Indonesia, Jakarta, 2019, page. 35-36. 
interests of victims of criminal acts. This service model should be applied in general, not only for the crime of trafficking in persons, but also for general crimes and so on.

Another factor that results in the ineffectiveness of the provisions concerning the granting of restitution rights to victims of criminal acts is because the perpetrators of criminal acts are generally underprivileged people. In this regard, basically the purpose of criminal law is to protect individual interests, human rights and society. In line with that, Sudarto also stated that the function of criminal law is divided into two things, namely: ${ }^{19}$

g. The general function is that criminal law is a part of law, so that its function lies more in regulating community life or administering legal traffic in society.

h. Its special function is to protect legal interests against an act that rapes her with a criminal sanction that is sharper in nature when compared to the sanctions found in other branches of law.

Referring to such goals and functions, the enforcement of criminal law is an effort to create an orderly life in society by protecting individual interests and human rights in social life. In this context, criminal offenders who are less well off have great potential not to pay restitution for victims of criminal acts. The existence of a reality like this is certainly very detrimental to victims of criminal acts, considering that the fulfillment of restitution rights is an effort to restore the victim's condition to its original state. The reason behind the non-payment of the right to restitution is not only because of the inability factor but also because the perpetrators of the criminal act believe that the fulfillment of the payment of the right to restitution cannot eliminate the basic criminal, whether in the form of imprisonment, imprisonment, or anything else. The other side of that, in PP. 44 of 2008 concerning Compensation, Restitution and Funding Assistance to Witnesses and Victims also has not found alternatives when the right to restitution has not been paid. It cannot be denied that PP. 44 of 2008 also contains the provision of compensation rights. According to Article 1 paragraph (4) Compensation is compensation provided by the state because the perpetrator is unable to provide full compensation for which he is responsible. However, the payment of compensation like this is only intended for victims of gross human rights violations and criminal acts of terrorism. ${ }^{20}$ Provisions for fulfilling the rights of restitution for underprivileged offenders should be included in additional penalties, so that the perpetrators of criminal acts have no more reasons for not fulfilling the restitution rights that should be received by the victims. The other side of that, the existence of additional penalties regarding the fulfillment of restitution rights should also have the power of coercion as contained in the Draft Criminal Code. Article 94 paragraph (1) of the RKUHP states that in a court decision the convict's obligation to pay compensation to the victim or heir may be stipulated as an additional penalty as referred to in

19 Tian Terina and Fatkhur Rochman, Concept of Death Penalty from a Penitentiary Law, Ismaya Publishing, Malang, 2020, page. 28.

20 Harris YP Sibuea, Legal Issues on Restitution for Child Victims of Crime, Legal Brief Information Magazine, Vol. IX, No. 21, 2017, p. 2. 
Article 66 paragraph (1) letter d. Furthermore, Article 94 paragraph (2) also states that if the obligation to pay compensation as referred to in paragraph (1) is not carried out, then the provisions on the implementation of fines as referred to in Article 81 to Article 83 shall apply mutatis mutandis. Furthermore, criminal sanctions for perpetrators of underprivileged crimes should be in the form of social work criminal sanctions, so that all income from social work can be used to fulfill restitution rights for the victims and the families of the perpetrators of the criminal acts who have been left behind. The existence of a solution like this can also be contextualized to the object of the criminal act that has been transferred or consumed by the perpetrator of the crime, so that the victim gets rights in accordance with the provisions of the laws governing it.

Regardless of this context, the third factor of the ineffectiveness of regulations regarding restitution rights is due to the absence of good faith from the perpetrators of criminal acts who have adequate financial capacity. The absence of good faith is because the perpetrators of the criminal act consider that the imprisonment that must be committed is a punishment commensurate with the suffering that has been experienced by the victim. In connection with this fact, the payment of restitution rights to victims should also be included in additional penalties that must be paid by the perpetrator of the crime and Article 94 of the RKUHP has been applied as explained above. Furthermore, it is also necessary to provide regulations regarding the confiscation of the property of the perpetrator of a criminal offense, when he does not wish to fulfill the rights of the victim.

\section{CONCLUSION}

The factors behind the ineffective fulfillment of restitution rights for victims of crime are caused by three factors, namely: Disobedience of victims who are actually cloud people regarding the rights of retribution, compensation and rehabilitation. along with the procedures for filing it. In addition, the ineffectiveness of the payment of restitution rights is also due to the fact that the perpetrators of criminal acts are generally underprivileged people, so that they can only surrender themselves to waiting for justice through court decisions. Furthermore, the ineffectiveness of the regulations on the fulfillment of the right to retribution and compensation is because the perpetrators of criminal acts, who generally have adequate financial capacity, do not have good faith, because the perpetrators of criminal acts think that imprisonment is a punishment that is commensurate with the suffering experienced by the victim, so that the perpetrators considered that the punishment they experienced had provided the victim with inner satisfaction.

The application of the service model for victims of crime in fulfilling the rights of restitution, compensation and rehabilitation should position the victim as a subject who requires extra services, as stated in Law No. 21 of 2007 concerning the Eradication of the Crime of Trafficking in Persons. In this Law, the fulfillment of the right to restitution, aspiratively positions the victim as the party who is in dire need of service. This refers to the Elucidation of Article 48 paragraph (1) which states that the mechanism for filing for restitution is carried out since the victim reports 
the case he has experienced to the local police and is handled by the investigator at the same time as the handling of the criminal act committed. Furthermore, the public prosecutor conveyed to the victim his right to apply for restitution and conveyed the amount of losses suffered by the victim as a result of the criminal act of trafficking in persons together with the charges. The mechanism for fulfilling restitution like this certainly requires law enforcers to play a dual role, namely handling criminal cases and taking care of all the interests of victims of criminal acts. In addition, the reconstruction of the fulfillment of restitution rights for underprivileged criminal offenders and criminal offenders who do not have good faith should this payment be used as additional crimes, and the perpetrators of less capable crimes are sentenced to social work penalties. By convicting the underprivileged offender into a social work punishment, the income he earns can be used to meet the payment for the right to restitution and fulfill the needs of the family he has left behind.

\section{BIBLIOGRAPHY}

\section{Books:}

Has Scientific Hamid, 2018, Legal Protection Against Victims of Torture in Handling Crime, OSF.IO;

Lysa Anggraini, 2018, The Effectiveness of Rehabilitation of Drug Addicts and Its Effects on Crime in Indonesia, Uwais Inspirasi Indonesia, Jakarta;

Ratih Wulandari, 2020, Legal Protection Government Employees with Work Agreements at Regional General Hospitals, Scopindo Media Pustaka, Surabaya;

S. Aminah and Rolkan, 2019, Introduction to Qualitative Research Methods, Prenadamedia Group, Jakarta;

Sujoko, 2008, Implementation of Claims for Compensation in Article 98 of the Criminal Procedure Code against the Crime of Rape in Semarang Legal Area, Thesis, Diponegoro University, Semarang;

The Indonesian Attorney's Office for Education and Training, 2019, Prosecutors' Office Module on Crime of Trafficking in Persons, the Education and Training Agency for the Republic of Indonesia, Jakarta;

Tian Terina and Fatkhur Rochman, 2020. Concept of Death Penalty from a Penitentiary Law, Ismaya Publishing, Malang;

Y. Sri Pudyatmoko, 2009, Licensing: Problems and Remedies, Grasindo, Jakarta;

Yesmil Anwar, 2008. Introduction to Sociology of Law, Grasindo, Jakarta;

\section{Journals:}

Alvianto RV Ransun, Mechanism for Providing Compensation and Restitution for Victims of Crime, Lex Crimen, Vol. 1, No. 1, 2012; 
Ferry Irawan Febriansyah, Justice Based on Pancasila as a Philosophical Basis and National Ideology, DIH Journal of Legal Sciences, Vol. 13, No. 25, 2017;

Harris YP Sibuea, Legal Issues on Restitution for Child Victims of Crime, Legal Brief Information Magazine, Vol. IX, No. 21, 2017;

Rena Yulia, Reviewing the Position of Crime Victims in the Criminal Justice System, Mimbar Hukum, Vol. 28, No. 1, 2016; 